J. Perinat. Med. 15 (1987) 555

\title{
Blood and milk concentrations of ampicillin in mothers treated with pivampicillin and in their infants
}

\author{
Poul Erik Branebjerg and Lars Heisterberg \\ Department of Obstetrics and Gynecology G, Gentofte Hospital, University of \\ Copenhagen, Denmark
}

\section{Introduction}

Pivampicillin is a commonly used antibiotic in the therapy of puerperal infections. In humans pivampicillin is almost completely transformed into ampicillin which is the biologically active component. To our knowledge, only one investigation has determined the amount of an ampicillin excreted in human milk [1]. Several reports on concentrations of ampicillin in milk from animals have been published $[7,8]$. The object of the present study was to determine the levels of ampicillin in blood and milk of mothers in therapy with pivampicillin and in the blood of their suckling infants thereby estimating the dose a neonate may receive. Also, we have analyzed blood and milk samples from 4 mothers for a longer period in an attempt to find a time when levels in plasma and milk reached an equilibrium. Finally, we have calculated the milk-plasma $(\mathrm{M} / \mathrm{P})$ ratio and the degree of protein binding of ampicillin in milk.

\section{Material and methods}

Fourteen mothers with puerperal infections requiring antibiotic treatment gave informed consent to participate. Nine mothers receiving pivampicillin tablets $350 \mathrm{mg}$ t.d.s. had blood sampled 2 and 4 hours after the last tablet and at breast feeding. Three mothers receiving pivampicillin tablets $350 \mathrm{mg}$ t.d.s. and two mothers receiving $700 \mathrm{mg}$ t.d.s. had blood sampled immediately before medication and then every half hour for 2 hours and every one hour for 4 to 6 hours after medication.
Milk samples were collected during feeding. One hour later a blood sample was drawn from the infants.

Medication was started from 0 to 22 days after parturition and no sample collected until at least 24 hours after start of pivampicillin therapy. All mothers received metronidazole tablets $200 \mathrm{mg}$ t.d.s. during the test period, but no other medication.

All samples were analyzed by microbiologic method [2], the lower limit of detection being $0.03 \mu \mathrm{g} / \mathrm{ml}$. The test bacteria were not sensitive to metronidazole. A non-specific antibiotic inhibition was observed in the milk, but it was eliminated by dilution.

Ampicillin was added to four milk samples from non-medicated mothers. Two concentrations, i. e. $0.3 \mu \mathrm{g} / \mathrm{ml}$ and $3 \mu \mathrm{g} / \mathrm{ml}$, were used and levels in the ultra filtrate were measured. The amount of recovered free antibiotic was then determined.

When the study was commenced, no ethical committee was operative in the area.

\section{Results}

Concentrations of ampicillin in blood and milk from 9 mothers are shown in table I. Concentrations from 5 mothers, who had samples collected for a longer period, are shown in table II.

No antibacterial activity was observed in any of the infant blood samples, i.e. all samples contained less than $0.03 \mu \mathrm{g}$ ampicillin per ml blood. 
Table I. Plasma and milk levels $(\mu \mathrm{g} / \mathrm{ml})$ of ampicillin and milk-plasma $(\mathrm{M} / \mathrm{P})$ ratios in 9 women in therapy with pivampicillin $350 \mathrm{mg}$ t.d.s.; time after medication in minutes.

\begin{tabular}{lrlrlll}
\hline Patient & \multicolumn{2}{c}{ Plasma } & & \multicolumn{2}{c}{ Milk } & \multicolumn{1}{c}{$\begin{array}{c}\text { M/P } \\
\text { ratio }\end{array}$} \\
\cline { 2 - 3 } & Time & Level & & Time & Level & \\
\hline 1 & 260 & 1.10 & & 260 & 0.10 & 0.09 \\
2 & 255 & 0.78 & & 255 & 0.06 & 0.07 \\
3 & 60 & 8.20 & 60 & 0.08 & 0.01 \\
4 & 60 & 1.10 & 60 & 0.17 & 0.15 \\
5 & 140 & 4.00 & & 140 & 0.11 & 0.03 \\
6 & 130 & 2.70 & 130 & 0.06 & 0.02 \\
7 & 260 & 0.33 & 260 & 0.19 & 0.58 \\
8 & 270 & 0.51 & 270 & 0.07 & 0.14 \\
9 & 250 & 0.45 & 250 & 0.06 & 0.13 \\
\hline
\end{tabular}

Maximum concentrations in plasma are reached 60 to 120 minutes after oral intake of pivampicillin. In milk, maximum levels are reached 180 to 240 minutes after medication. There is most likely a significant delay before a balance between levels in blood and milk is reached. This delay is estimated to be 100 to 180 minutes. When the balance is obtained, levels in milk seem to vary very little.

The milk-plasma $(\mathrm{M} / \mathrm{P})$ ratio is normally calculated on the basis of simultaneous samples from blood and milk. Such a calculation gives a wide range, i. e. $0.01-0.58$, of $\mathrm{M} / \mathrm{P}$ values (table I).

The recovery rate of ampicillin in the ultra filtrate was 94 to $105 \%$. As the variance of analysis with this method is $5-10 \%$, ampicillin is found not to be bound to protein in human milk.

\section{Discussion}

Administration of drugs to lactating mothers always raises the question of a possible harmful effect of the drug on the suckling infant. The excretion of drugs from plasma to milk is by most believed to take place by passive diffusion controlled by the difference in plasma and milk $\mathrm{pH}$ and by protein binding in plasma and milk [3].

Drugs, which have a high degree of protein binding in plasma, have been shown not to pass into milk [4]. Drugs, which are neutrally reacting or with a small molecular weight, pass freely into milk and are found in equal concentrations in plasma and milk [4].

Most drugs are either weak acids or weak bases. As $\mathrm{pH}$ in milk is 6.85 and in plasma 7.4 , weak bases will concentrate in milk and weak acids will occur in lower concentrations than in plasma [3].

Ampicillin is an ampholyte with two $\mathrm{pKa}$ values, 2.7 and 7.2 at $\mathrm{pH} \mathrm{7.0.} \mathrm{As} \mathrm{a} \mathrm{consequence} \mathrm{it} \mathrm{will}$ mainly be acting as a weak acid and the significant $\mathrm{pKa}$ value will be 2.7. Using a modification of the Hasselbalch-Henderson equation [3] and with $\mathrm{pH}$ for milk and plasma being 6.85 and 7.4, respectively, $\mathrm{M} / \mathrm{P}$ ratio can be calculated to be 0.28 .

The basis for the above calculation is an equilibrium between milk and plasma levels. This is not

Table II. Plasma and milk levels $(\mu \mathrm{g} / \mathrm{ml})$ of ampicillin in 3 women $(\mathrm{A}, \mathrm{B}, \mathrm{C})$ receiving pivampicillin $350 \mathrm{mg}$ t. d. s. and in 2 women $(\mathrm{D}, \mathrm{E})$ receiving $700 \mathrm{mg}$ t. d. s.; time after medication in minutes.

\begin{tabular}{|c|c|c|c|c|c|c|c|c|c|c|}
\hline \multirow[t]{2}{*}{ Patient } & & \multicolumn{9}{|l|}{ Time } \\
\hline & & 0 & 30 & 60 & 90 & 120 & 180 & 240 & 300 & 360 \\
\hline A & $\begin{array}{l}\text { Level plasma } \\
\text { Level milk }\end{array}$ & $\begin{array}{l}0.04 \\
0.044\end{array}$ & $\begin{array}{l}2.04 \\
0.048\end{array}$ & $\begin{array}{l}3.28 \\
0.058\end{array}$ & $\begin{array}{l}1.89 \\
0.076\end{array}$ & & & $\begin{array}{l}0.25 \\
0.074\end{array}$ & $\begin{array}{l}0.12 \\
0.061\end{array}$ & $\begin{array}{l}0.06 \\
0.061\end{array}$ \\
\hline B & $\begin{array}{l}\text { Level plasma } \\
\text { Level milk }\end{array}$ & $\begin{array}{l}0.060 \\
0.040\end{array}$ & $\begin{array}{l}3.04 \\
0.034\end{array}$ & $\begin{array}{l}3.57 \\
0.049\end{array}$ & $\begin{array}{l}2.75 \\
0.049\end{array}$ & $\begin{array}{l}1.94 \\
0.072\end{array}$ & & $\begin{array}{l}0.37 \\
0.082\end{array}$ & 0.067 & $\begin{array}{l}0.09 \\
0.060\end{array}$ \\
\hline $\mathrm{C}$ & $\begin{array}{l}\text { Level plasma } \\
\text { Level milk }\end{array}$ & $\begin{array}{l}0.36 \\
0.11\end{array}$ & $\begin{array}{l}0.61 \\
0.13\end{array}$ & $\begin{array}{l}1.42 \\
0.11\end{array}$ & & $\begin{array}{l}2.60 \\
0.11\end{array}$ & $\begin{array}{l}1.42 \\
0.11\end{array}$ & $\begin{array}{l}0.79 \\
0.13\end{array}$ & & \\
\hline $\mathrm{D}$ & $\begin{array}{l}\text { Level plasma } \\
\text { Level milk }\end{array}$ & $\begin{array}{l}9.23 \\
0.25\end{array}$ & 0.35 & $\begin{array}{l}12.26 \\
0.55\end{array}$ & & $\begin{array}{l}13.83 \\
0.55\end{array}$ & $\begin{array}{l}5.07 \\
1.02\end{array}$ & $\begin{array}{l}2.09 \\
0.80\end{array}$ & $\begin{array}{l}1.40 \\
0.64\end{array}$ & $\begin{array}{l}0.74 \\
0.65\end{array}$ \\
\hline $\mathrm{E}$ & $\begin{array}{l}\text { Level plasma } \\
\text { Level milk }\end{array}$ & $\begin{array}{l}2.88 \\
0.32\end{array}$ & $\begin{array}{l}5.42 \\
0.33\end{array}$ & $\begin{array}{l}8.28 \\
0.32\end{array}$ & $\begin{array}{l}6.65 \\
0.38\end{array}$ & $\begin{array}{l}3.92 \\
0.34\end{array}$ & $\begin{array}{l}1.55 \\
0.40\end{array}$ & $\begin{array}{l}0.79 \\
0.41\end{array}$ & & \\
\hline
\end{tabular}


obtained during normal therapeutic medication as ampicillin has a half life of 2 hours. This explains the time difference in maximum levels in milk and plasma.

From our findings that the ampicillin protein binding in milk is 0 and the one in plasma is reported to be $18 \%$ [4], the $M / P$ ratio must be reduced to 0.23 . The discrepancy with our result of an $\mathrm{M} / \mathrm{P}$ ratio at 0.10 (average of $M / P$ values in table I) is probably due to the fact that an equilibrium is never obtained because of decreasing levels of ampicillin in plasma. From the only previous report on ampicillin excretion in human milk [1] can be found $M / P$ ratios varying between 0.02 and 3.0 with a mean of 0.3 . Dosage was 500 mg ampicillin every 6 hours and milk and blood were sampled simultaneously. $\mathrm{M} / \mathrm{P}$ ratios reported for other penicillins are in accordance with our findings [6].

The daily maximum ampicillin dose an infant has received from a mother in the present study assuming a milk consumption of $500 \mathrm{ml}$ per day has been $500 \mathrm{ml} \times 1.02 \mu \mathrm{g} / \mathrm{ml}=0.5 \mathrm{mg}$ (table II). This amount is insignificant and cannot explain reported incidents of diarrhoea and candidiasis in suckling infants whose mothers received ampicillin [5].

Allergic erythema has not been reported in suckling infants, but sensibilization even with a low dose of ampicillin is possible and should be kept in mind.

\section{Abstract}

The levels of ampicillin were determined in milk and plasma of 14 lactating mothers in treatment with pivampicillin for puerperal infections and in plasma of their suckling infants.

Ampicillin could not be detected in plasma of the infants, i. e. all levels were less than $0.03 \mu \mathrm{g} / \mathrm{ml}$. Maximum levels occurred in plasma 60-120 minutes and in milk
180-240 minutes after medication. Milk-plasma ratios varied between 0.01 and 0.58 . The highest level of ampicillin in milk was $1.02 \mu \mathrm{g} / \mathrm{ml}$ in a woman receiving pivampicillin tablets $700 \mathrm{mg}$ t.d. s. At this level an infant can at the most ingest $0.5 \mathrm{mg} / \mathrm{day}$. This dose is too small to cause any symptoms in the suckling infants, but allergic sensibilization through the milk is possible.

Keywords: Ampicillin, infant dosage, lactation, milk levels, pivampicillin, plasma levels, protein binding.

\section{Zusammenfassung}

Konzentration von Ampicillin in Blut und Milch bei mit Pivampicillin behandelten Müttern und bei ihren Kindern Im Plasma und in der Milch von 14 stillenden Müttern, die wegen einer Wochenbettinfektion mit Pivampicillin behandelt wurden, und im Plasma ihrer Säuglinge wurde der Ampicillin-Gehalt bestimmt.

Im Plasma der Kinder wurde kein Ampicillin gefunden; d. h. alle Werte lagen unter $0,03 \mu \mathrm{g} / \mathrm{ml}$. Höchstwerte traten im Plasma 60-120 Min. und in der Milch 180-
240 Min. nach der Medikation auf. Das Milch-PlasmaVerhältnis variierte zwischen 0,01 und 0,58 . Der höchste Ampicillin-Wert in der Milch mit $1,02 \mu \mathrm{g} / \mathrm{ml}$ wurde bei einer Frau gefunden, die Pivampicillin Tabletten $700 \mathrm{mg}$ $3 \times$ tägl. erhielt. Bei dieser Menge kann ein Kind bis zu $0,5 \mathrm{mg}$ pro Tag aufnehmen. Die Dosis ist jedoch zu klein, um bei dem Säugling Symptome hervorzurufen; eine allergische Sensibilisierung durch die Milch ist aber möglich.

Schlüsselwörter: Ampicillin, kindliche Dosis, Laktation, Milch-Werte, Pivampicillin, Plasma-Werte, Proteinbindung.

\section{Résumé}

Concentration d'ampicilline dans le sang et le lait des mères traitées par pivampicilline et concentration chez leurs enfants

On a dosé les taux d'ampicilline dans le lait et le plasma de 14 mères en cours d'allaitement, traitées par pivampicilline pour infections puerpérales, ainsi que dans le plasma de leurs enfants nourris au sein.
L'ampicilline n'a pas pu être détectée dans le plasma des enfants, c'est-à-dire que tous les taux étaient inférieurs à $0,03 \mu \mathrm{g} / \mathrm{ml}$. Après la prise médicamenteuse les taux maximum s'observent dans le plasma entre 60 to 120 minutes et dans le lait entre 180 et 240 minutes. Les rapports entre le lait et le plasma varient entre 0,01 et 0,58 . Le taux le plus élevé d'ampicilline dans le lait a 
été de $1,02 \mu \mathrm{g} / \mathrm{ml}$ chez une patiente prenant des gélules d'ampicilline à $700 \mathrm{mg}$. A ce taux un enfant peut recevoir au plus $0,5 \mathrm{mg}$ par jour. Cette dose est trop faible pour provoquer quelque symptome que ce soit chez un enfant nourri au sein, mais une sensibilisation allergique via le lait est possible.

Mots-clés: Allaitement, ampicilline, dosage chez l'enfant, pivampicilline, protéine de transport, taux dans le lait, taux plasmatique.

\section{References}

[1] LOHMEYeR H, E HALFPAP: Pharmakokinetische Untersuchungen und klinische Erfahrungen mit Ampicillin bei der Behandlung von Infektionen des Urogenitaltrakts der Frau. Z Geburtshilfe Gynäkol 164 (1965) 184

[2] Lunde PKM, A RaNe, SJ YafFe, L Lund, F SJöQVIST: Plasma protein binding of diphenylhydantoin in man. Clin Pharmacol Ther 11 (1970) 846

[3] RASMuSSEN F: Studies on the mammary excretion and absorption of drugs. Carl Fr. Mortensen, Copenhagen 1966

[4] Rolinson GN: The significance of protein binding of antibiotics in antibacterial chemotherapy. J Antimicrobiol Chemother 6 (1980) 311

[5] Williams M: Excretion of drugs in milk (letter). Pharm J Sept 18 (1976) 219
[6] Wilson JT, RD Brown, DR ChereK, JW DaIley, B Hilman, PC Jobe, BR Manno, JE Manno, HM REDETZKI, JJ STEWART: Drug excretion in human breast milk. Clin Pharmacokinetics 5 (1980) 1

[7] Ziv G, FG Sulman: Effects of probenicid on the distribution, elimination, and passage into milk of benzylpenicillin, ampicillin and cloxacillin. Arch Int Pharmacodyn Ther 207 (1974) 373

[8] Ziv G, S Gordin, G Bechar, S Bernstein: Binding of antibiotics to dry udder secretion and to udder homogenates. Br Vet J 132 (1976) 318

Received September 12, 1986. Revised December 3, 1986. Accepted December 28, 1986.

Lars Heisterberg, M. D.

Åbrinken 24

DK-2830 Virum, Denmark 